\title{
High Mutation Rates in Canine Tetranucleotide Microsatellites: Too Much Risk for Genetic Compatibility Purposes?
}

\author{
David Parra $^{1}$, David García ${ }^{2}$, Susy Mendez ${ }^{2}$ Javier Cañon ${ }^{2}$, Susana Dunner*,2 $^{*}$ \\ ${ }^{I}$ Departamento de Biología, Servicio de Criminalística de la Guardia Civil, Calle Guzmán el Bueno 110, 28003 Madrid, \\ Spain; ${ }^{2}$ Laboratorio de Genética, Facultad de Veterinaria, Universidad Complutense de Madrid, 28040 Madrid, Spain
}

\begin{abstract}
The use and convenience of canine tetranucleotide microsatellite markers for forensic purposes is addressed. These are commonly used in human genetics due to their high polymorphism, ease of laboratorial management and low mutation rates. However, care should be taken before including these markers in canine panels due to the high mutation rates shown in this species and the risk of errors in paternity assignment. To answer this question a panel including 16 markers ( 8 of them tetranucleotides) were typed for the family members of the Dogmap Project reference panel, and their mutation rates calculated. The effect these rates would have in terms of the increase in the number of false positives is assessed. Excluding one single marker with extreme mutation rate from the panel considerably improves the average rate and the performance of the panel. Therefore, a careful examination of the mutational behaviour of the candidate markers is advised for any marker panel design, even prior to the assessment of their polymorphism.
\end{abstract}

Keywords: Canine, microsatellite, mutation, genetic compatibility.

\section{INTRODUCTION}

Microsatellite typing is one of the most used tools to obtain DNA profiles for individual identification, genetic compatibility and traceability purposes, but also for other kind of studies, like measuring populations, genetic diversity or linkage analysis. They are based on sequence blocks of one to six nucleotides tandemly repeated a variable number of times and represent $0.3 \%$ of the nuclear genome [1,2]. High polymorphism, simplicity of analysis and low-cost make microsatellites an advantageous choice for paternity testing and genetic identification. Using a set of hyperpolymorphic markers usually leads to a high power of exclusion on kinship analysis, close to $99.99 \%$ [3, 4].

Mutations are the main source of genetic variation, originating in microsatellites new alleles with modified length. Mutation rates in different organisms range from $10^{-2}$ events per locus and replication [5] to $6 \times 10^{-6}[6]$, higher than the mutation rates per base pair estimated from specific loci in eukaryotes, that ranges from $2 \times 10^{-10}$ to $5 \times 10^{-10}$ [7]. In dogs, mutation rates in microsatellites vary from $1.1 \times 10^{-2}$ to $3.9 \times 10^{-3}$ [8-10]. Tetranucleotide STRs in humans account for lower mutation rates than dinucleotide microsatellites [11] and are preferred markers for genetic typing due to their sufficiently high polymorphism, ease of read or calling, absence of stutter bands. However, in the canine species, tetranucleotide STRs are described as specially highly polymorphic, (mean PIC > 75\%) [8], this data being particularly relevant in the canine species where the whole population is stratified

*Address correspondence to this autor at the Dpto Producción Animal, Facultad de Veterinaria, Universidad Complutense de Madrid, 28040 Madrid, Spain; Tel: +34913943765; Fax: +34913943772;

E-mail: dunner@vet.ucm.es in more than 350 breeds and genetic lines, so that the possible genetic homogeneity could require the use of very highly polymorphic markers [8].

Genetic identification is attracting an increasing interest in genetic dog forensic sciences [12]. Not only can it help to resolve cases of individual identification on disputes or for animals included in a herd book, but also it can be a key tool in crime scenes or accidents, dogs or wolves attacks, homicides, to verify parentage or in paternity disputes between breeders and pet owners, genetic traceability, or even to discriminate canine or wolf populations [13-22]. Several STR panels have been proposed [3, 9, 10, 23-30], but their stability for possible mutations has not been achieved yet.

In this study we analyse a panel of 16 STR in which 8 markers are tetranucleotides and we describe the rate of mutation and identify specific mutational events cases in three markers and 3392 meiosis after genotyping the reference families of the DogMap Project.

\section{MATERIAL AND METHODS}

In order to build the linkage map in the frame of the DOGMAP PROJECT (www.dogmap.ch), the family members of the Reference Panel were typed for 16 microsatellites (7 with dinucleotide repeat unit, 8 tetranucleotide, and one pentanucleotide motifs, see Table 1). This panel comprises 8 families with a total of 129 individuals belonging to Beagle and German Shepherd breeds distributed as 23 parents and 106 offspring, and allows testing 212 meiosis per locus [8].

For each marker included in the panel, PCR was performed in a total volume of $10 \mu \mathrm{l}$ of the following mixture: $10 \mathrm{ng}$ of genomic DNA, 6-10 pmol of each primer, $200 \mu \mathrm{M}$ of each dNTP, $1.5 \mathrm{mM} \mathrm{MgCl}_{2}, 1 \times$ PCR Buffer $[75 \mathrm{mM}$ Tris$\mathrm{HCl}\left(\mathrm{pH} \mathrm{9.0)}, 50 \mathrm{mM} \mathrm{KCl}, 20 \mathrm{mM}\left(\mathrm{NH}_{4}\right)_{2} \mathrm{SO}_{4}, 0.001 \%\right.$ BSA] and $0.3 \mathrm{U}$ of thermostable DNA polymerase (Biotools, Madrid 28080 , E). The cycling programme in a PTC- $200^{\mathrm{TM}}$ 
Table 1. Main Features of the Microsatellites Studied. Confidence Intervals $(95 \%)$ of Estimated Mutation Rates are Shown in Brackets

\begin{tabular}{|c|c|c|c|c|c|c|}
\hline LOCUS & Repeat Motif & $\begin{array}{c}\text { Number of } \\
\text { Alleles } \\
\text { Observed }\end{array}$ & Range (bp) & Primer Sequence $\left(5^{\prime} \rightarrow 3^{\prime}\right)$ & Mutation Rate & References \\
\hline АНT002 & $(\mathrm{CA})_{\mathrm{n}}$ & 5 & $132-150$ & $\begin{array}{l}\text { F: CCCAATACAGCAAGACCTCT } \\
\text { R: ACCTACTCTGCACAGAGAAG }\end{array}$ & $\begin{array}{c}0 \\
(0,00000-0,01725)\end{array}$ & [23] \\
\hline DGN8 & $(\text { GAAA })_{n}$ & 7 & $189-273$ & $\begin{array}{c}\text { F: GTGGATTACCTATTTTTGTGCC } \\
\text { R: TATTCTGTATGTTGGTAAATTGAA }\end{array}$ & $\begin{array}{c}0 \\
(0,00000-0,01725)\end{array}$ & [35] \\
\hline DGN13 & $(\text { GAAA })_{n}$ & 8 & $275-349$ & $\begin{array}{l}\text { F: GGAACCCTCAGCTTATTATGC } \\
\text { R: GATCTAAGGGCTCCAGAACACC }\end{array}$ & $\begin{array}{c}0 \\
(0,00000-0,01725)\end{array}$ & {$[35]$} \\
\hline D-INRA2 & $(\mathrm{CT})_{\mathrm{n}}$ & 7 & $137-213$ & $\begin{array}{l}\text { F: GTCTGACTATTCCCAAGTAGC } \\
\text { R: CCTAGAAATGGCAGATAACAC }\end{array}$ & $\begin{array}{c}0 \\
(0,00000-0,01725)\end{array}$ & [35] \\
\hline FH2062 & $(\mathrm{GAAT})_{\mathrm{n}}$ & 2 & $124-140$ & $\begin{array}{l}\text { F: GGCTTCTGGAGACAGGCAT } \\
\text { R: CAGAACGCTGTCTAGCCCTT }\end{array}$ & $\begin{array}{c}0 \\
(0,00000-0,01725)\end{array}$ & [3] \\
\hline FH2109 & $(\mathrm{GATT})_{\mathrm{n}}$ & 3 & $172-180$ & $\begin{array}{l}\text { F: CAATCCAGCAACCCTCATCT } \\
\text { R: CAGGGATTGAGTCCCACATC }\end{array}$ & $\begin{array}{c}0 \\
(0,00000-0,01725)\end{array}$ & [3] \\
\hline FH2119 & $(\text { GAAAA })_{n}$ & 6 & $167-327$ & $\begin{array}{l}\text { F: AGTTGTCAGCATTGTTTTCTCA } \\
\text { R: TTCAGTCTGGTATGCAATGTCC }\end{array}$ & $\begin{array}{c}0 \\
(0,00000-0,01725)\end{array}$ & [3] \\
\hline FH2140 & $(\text { GAAA })_{n}$ & 8 & $128-166$ & $\begin{array}{l}\text { F: GGGGAAGCCATTTTTAAAGC } \\
\text { R: TGACCCTCTGGCATCTAGGA }\end{array}$ & $\begin{array}{c}0.0047 \\
(0,00012-0,02600)\end{array}$ & [3] \\
\hline FH2168 & $(\text { GAAA })_{n}$ & 9 & $160-200$ & $\begin{array}{c}\text { F: GCAAATTACT TACTTCACTA TGCC } \\
\text { R: TTGCAAGACT TCAACATGGC }\end{array}$ & $\begin{array}{c}0.0092 \\
(0,00115-0,03366)\end{array}$ & [3] \\
\hline FH2201 & $(\text { GAAA })_{n}$ & 6 & $150-260$ & $\begin{array}{c}\text { F: ATCAACAATGCATGCCACAT } \\
\text { R: GAGAACAAATAAATGCAAGCCC }\end{array}$ & $\begin{array}{c}0.0236 \\
(0,00770-0,05418)\end{array}$ & [3] \\
\hline LEI008 & $(\mathrm{CA})_{\mathrm{n}}$ & 4 & $150-162$ & $\begin{array}{l}\text { F: CGATCTCAACCTGAAGCATG } \\
\text { R: GGGTGTCTCATTCCGGTTGC }\end{array}$ & $\begin{array}{c}0 \\
(0,00000-0,01725)\end{array}$ & [36] \\
\hline TAT & $(\mathrm{GT})_{\mathrm{n}}$ & 4 & $116-126$ & $\begin{array}{l}\text { F: GGCAATGAGGTAAGAGCAATGTGGTG } \\
\text { R: ACAAAATCACCTCCTAACCACTGTG }\end{array}$ & $\begin{array}{c}0 \\
(0,00000-0,01725)\end{array}$ & [37] \\
\hline UCMCF12 & $(\mathrm{AAAT})_{\mathrm{n}}$ & 4 & $135-151$ & $\begin{array}{c}\text { F: ATCTGTAGTAAAGCTGAC } \\
\text { R: GGAGCTCTCTGCTCAGTATG }\end{array}$ & $\begin{array}{c}0 \\
(0,00000-0,01725)\end{array}$ & [38] \\
\hline UCMCF40 & $(\mathrm{GT})_{\mathrm{n}}$ & 6 & $107-121$ & $\begin{array}{c}\text { F: CATTCCTTTTCATGTATAT } \\
\text { R: TTTACAACCTAAATGTCCTTG }\end{array}$ & $\begin{array}{c}0 \\
(0,00000-0,01725)\end{array}$ & {$[38]$} \\
\hline UCMCF71 & $(\mathrm{GT})_{\mathrm{n}}$ & 3 & $142-156$ & $\begin{array}{l}\text { F: AAGAAGCTGCAGGAGCTACG } \\
\text { R: ACTCAAAAGCCATCTTGTCACA }\end{array}$ & $\begin{array}{c}0 \\
(0,00000-0,01725)\end{array}$ & [38] \\
\hline UCMCF96 & $(\mathrm{GT})_{\mathrm{n}}(\mathrm{CA})_{\mathrm{n}}$ & 7 & $225-243$ & $\begin{array}{l}\text { F: GAGCAGCAGCTTCAGACTAC } \\
\text { R: GGTCGACTCTAGAGGATCTGG }\end{array}$ & $\begin{array}{c}0 \\
(0,00000-0,01725)\end{array}$ & [38] \\
\hline
\end{tabular}

Programmable Thermal Controller (MJ Research Inc., Watertown, USA) included initial denaturalization during $5 \mathrm{~min}$ at $95{ }^{\circ} \mathrm{C}, 30$ cycles of denaturalization for $50 \mathrm{sec}$. at $95{ }^{\circ} \mathrm{C}$, $50 \mathrm{sec}$. of annealing at $50{ }^{\circ} \mathrm{C}$ or $63{ }^{\circ} \mathrm{C}, 50 \mathrm{sec}$ of extension at $72{ }^{\circ} \mathrm{C}$, and final extension at $72{ }^{\circ} \mathrm{C}$ for $5 \mathrm{~min}$. Electrophoresis was carried out in $7 \%$ polyacrylamide gels under denaturing conditions, followed by silver staining or automated in the capillary sequencer ABI-310 (Applied Biosystems, Foster
City, CA, USA). Reading and allele calling was performed by three different technicians.

\section{RESULTS}

After genotyping the individuals in the Reference Panel for all the 16 markers, eight mutation events were observed in a total of 3392 meiosis analysed, as shown in Table 2 . The 
mutation rates across the different markers used showed a wide range of variation, with an average of $3.5 \times 10^{-3}$ events per meiosis. When considering the type of the repeat motif, the rate changes from being practically undetectable on dinucleotide microsatellites to $4.71 \times 10^{-3}$ in tetranucleotide markers. Mutations were observed in three tetranucleotide microsatellites: one in FH2140, two in FH2168 and the remaining five, in FH2201, across three different families. None of the rest of markers showed mutations. The gain or loss of one repeat unit is the main cause of three of the four mutational events while loss of two repeat units account for the event in case 2. Mutational dynamics shows therefore a global balance towards the loss of one repeat unit. In of case 8 , the presence of a null allele is discarded by the height of the peak shown in the electropherogram. Focusing on the sex distribution of the origins of the mutations, in cases 1, 2, 3 and 8 it is possible to determine which of the parental alleles has mutated: in three of them, a maternal allele is involved, and only one has been transmitted by the male.

Microsatellite FH2201 shows the highest mutation rate, peaking at a remarkably high value $(2.35 \%)$, but from the total alleles of this marker, only alleles 4 and 5 are involved. In three cases, two similar events have been observed within the same family (cases $3-8,4-5$ and $6-7$ ). This may reflect different germinal lines present in the parents. None of the rest of markers showed mutations and therefore these 13 markers should be selected.

\section{DISCUSSION}

The canine species is genetically structured into multiple breeds and lines. This reduces the number of polymorphisms to be found within breeds for a given locus. Thus the need for the evaluation and selection of markers panels showing not only high polymorphism and power of discrimination, but also a high stability is necessary in order to avoid a high number of errors or non conclusive results in exclusion or assignment analyses. When designing a marker panel, the objective is to select from 8 to 12 of the microsatellites evaluated, according to their laboratorial suitability, stability and degree of polymorphism. Ideally, the chosen markers should be combined in one multiplex reaction, one electrophoresis in an automatic sequencer, and should be highly polymorphic in order to obtain a high power of discrimination among individuals. Tetra/pentanucleotide microsatellites are usually described to show higher levels of polymorphism than dinucleotides. However, for laboratorial works, markers with alleles not representing an exact number of repeats, with a bimodal allele distribution, silent alleles, high mutation rates or even with a high number of alleles (as considered in [31]) should be avoided, and therefore excluded from panels for forensic purposes. The high mutation rates in particular canine tetranucleotide microsatellites found in this work confirms the results found in previous literature $[3,8$, 11]. Ranging from $1.1 \times 10^{-2}$ to $3.9 \times 10^{-3}$ in $\operatorname{dogs}[3,8,9]$, they are one order of magnitude higher than those observed in human $[32,33]$. Higher mutation rates generate new alleles more frequently. Consequently, if an intermediate value of $3 \times 10^{-3}$ is considered, any single canine marker would generate on average almost 6 false results of parental incompatibility, and thus falsely excluding paternity, in every 1000 cases of paternity testing (the probability of having at least one mutation transmitted in the two alleles of the offspring equalling $1-\left[1-3 \times 10^{-3}\right]^{2}$ ). The use of a panel of ten tetranucleotide microsatellites with the mutation rate stated above, would lead to some 6 out of 100 cases recorded erroneously as paternity exclusions for a single parent contrast, with a doubled error rate when both parents are included. Therefore, checking every marker on a high number of meiosis is advisable when designing a microsatellite panel to discard those markers showing excessive mutation rate. When excluding FH2201 from the panel chosen in this study, the average mutation rate observed drops to $6.73 \times 10^{-4}$, (on average only 2 mutation events in around 3000 meiosis).

Some standard canine microsatellite panels are widely used for genetic identification and genealogical compatibility analysis, but they are mainly composed by tetranucleotide markers, chosen according to their supposed high degree of informativeness. For example, the International Society for Animal Genetics (ISAG, www.isag.org.uk) proposed in 2002 the consecutive use of two panels of 12 and 11 microsatellite markers (including 7 and 8 tetranucleotide markers respectively) combined into two multiplexes, the American Kennel Club chose a panel including 17 microsatellites (16 tetranucleotides and 1 trinucleotide-type [34]), and the commercial kit StockMarks ${ }^{\circledR}$ for Dogs Canine Genotyping Kit (Applied Biosystems, Foster City, CA, USA) is composed by 10 tetranucleotide microsatellites. Considering the described mutation rate of 3 to $4 \%$ o for the ISAG 2002 microsatellite

Table 2. Details of the Cases in which Mutational Events have been Observed. Mutated Parental Alleles are Indicated in Bold and Italics

\begin{tabular}{|c|c|c|c|c|c|c|c|c|}
\hline Microsatellite & $\mathrm{FH} 2140$ & FH2168 & FH2168 & FH2201 & FH2201 & FH2201 & FH2201 & FH2201 \\
\hline Father's genotype & $3-3$ & $3-6$ & $5-8$ & $5-5$ & $5-5$ & $4-4$ & $4-4$ & $2-4$ \\
\hline \multirow{2}{*}{ Balance } & Gain & Loss & Loss & Loss & Loss & Gain & Gain & Loss \\
\hline & 1 unit & 2 unit & 1 unit & 1 unit & 1 unit & 1 unit & 1 unit & 1 unit \\
\hline
\end{tabular}


canine panel, the first battery has an inherent error rate of $4.2 \%-5.6 \%$, while the second ranges from $4.8 \%$ to $6.4 \%$. So roughly, when considering paternity exclusion with one incompatibility, more than 4 or 5 true paternities out of every 100 will be falsely rejected with the first set of markers, or at least the analysis will be considered not conclusive. For the [27] and [34] panels, with 17 tetranucleotide markers, inherent error rate is as high as 10.2-13.6\%, and the theoretical error of the commercial panel is $6-8 \%$.

Dinucleotide microsatellites in human genetics have been reported to have higher mutation rates $\left(1.52 \times 10^{-3}\right)$ [34] than tetranucleotides $\left(0.93 \times 10^{-3}\right)$ [35], which, in addition to the high stability and ease of laboratorial manipulation of the latter [12] makes them be generally preferred for this analysis. The situation in dogs is reversed, with tetranucleotides showing higher mutation rates. These high rates and the presence of complex structures making their resolution difficult, turn the use of tetranucleotides in dogs into quite a problematic issue. But still, they are the markers of choice, following the trend in human genetics.

In conclusion, we recommend that, prior to inclusion in a canine panel test, tetranucleotide microsatellites stability should be evaluated, since some seem to be surprisingly unstable for this type of repeat motif.

\section{REFERENCES}

[1] Miesfeld, R.; Krystal, M.; Arnheim, N. A member of a new repeated sequence family which is conserved throughout eucaryotic evolution is found between the human delta and beta globin genes. Nucleic Acid Res., 1981, 9, 5931-5947.

[2] Hamada, H.; Petrino, M.G.; Kakunaga, T. A novel repeated element with Z-DNA- forming potential is widely found in evolutionarily diverse eukaryotic genomes. Proc. Natl. Acad Sci. USA, 1982, 79, 6465-6469.

[3] Fredholm, M.; Winterö A.K. Efficient resolution of parentage in dogs by amplification of microsatellites. Anim. Genet., 1996, 27, 19-23.

[4] Ichikawa, Y.; Takagi, K.; Tsumagari, S.; Ishihama, K.; Morita, M.; Kanemaki, M.; Takeishi, M.; Takahashi, H. Canine parentage testing based on microsatellite polymorphisms. J. Vet. Med. Sci., 2001, 63, 1209-1213.

[5] Levinson, G.; Gutman, G.A. Slipped-strand mispairing: a major mechanism for DNA sequence evolution. Mol. Biol. Evol., 1987, 4, 203-221.

[6] Schug, M.D.; Mackay, T.F.; Aquadro, C.F. Low mutation rates of microsatellite loci in Drosophila melanogaster. Nat. Genet., 1997, 15, 99-102.

[7] Drake, J.W.; Charlesworth, B.; Charlesworth D.; Crow J.F. Rates of spontaneous mutation. Genetics, 1998, 148, 1667-1686.

[8] Francisco, L.V.; Langston, A.A.; Mellersh, C.S.; Neal, C.L.; Ostrander, E.A. A class of highly polymorphic tetranucleotide repeats for canine genetic mapping. Mamm. Genome, 1996, 7, 359-362.

[9] Lingaas, F.; Sorensen, A.; Juneja, R.K.; Johansson, S.; Fredholm, M.; Wintero, A.K.; Sampson, J.; Mellersh, C.; Curzon, A.; Holmes, N.G.; Binns, M.M.; Dickens, H.F.; Ryder, E.J.; Gerlach, J.; Baumle, E.; Dolf, G. Towards construction of a canine linkage map: establishment of 16 linkage groups. Mamm. Genome, 1997, 8, 218-221

[10] Irion, D.N.; Schaffer, A.L.; Famula, T.R.; Eggleston, M.L.; Hughes, S.S.; Pedersen, N.C. Analysis of genetic variation in 28 dog breed populations with 100 microsatellite markers. J. Hered., 2003, 94, 81-87.

[11] Moretti, T.R.; Baumstark, A.L.; Defenbaugh, D.A.; Keys, K.M.; Smerick, J.B;. Budowle, B. Validation of short tandem repeats (STRs) for forensic usage: performance testing of fluorescent multiplex STR systems and analysis of authentic and simulated forensic samples. J. Forensic Sci., 2001, 46, 647-660.

[12] Budowle, B.; Garofano, P.; Hellman, A.; Ketchum, M.; Kanthaswamy, S.; Parson, W.; van Haeringen, W.; Fain, S.; Broad, T. Rec- ommendations for animal DNA forensic and identity testing. Int. $J$. Legal Med., 2005, 119, 295-302.

[13] Schneider, P.M.; Seo, Y.; Rittner, C. Forensic mtDNA hair analysis excludes a dog from having caused a traffic accident. Int. J. Legal Med., 1999, 112, 315-316.

[14] Brauner, P.; Reshef, A.; Gorski, A. DNA profiling of trace evidence-mitigating evidence in a dog biting case. J. Forensic Sci., 2001, 46, 1232-1234.

[15] Ellegren, H.; Savolainen, P.; Rosen, B. The genetical history of an isolated population of the endangered grey wolf; Canis lupus: a study of nuclear and mitochondrial polymorphisms. Philos. Trans. R. Soc. Lond. B. Biol. Sci., 1996, 351(1348), 1661-1669.

[16] Savolainen, P.; Arvestad, L.; Lundeberg, J. A novel method for forensic DNA investigations: repeat-type sequence analysis of tandemly repeated mtDNA in domestic dogs. J. Forensic Sci., 2000, 45, 990-999.

[17] Savolainen, P.; Lundeberg, J. Forensic evidence based on mtDNA from dog and wolf hairs. J. Forensic Sci., 1999, 44, 77-81.

[18] Padar, Z.; Angyal, M.; Egyed, B.; Furedi, S.; Woller, J.; Zoldag, L.; Fekete, S. Canine microsatellite polymorphisms as the resolution of an illegal animal death case in a Hungarian zoological gardens. Int. J. Legal Med., 2001, 115, 79-81.

[19] Padar Z; Egyed, B.; Kontadakis, K.; Zoldag, L.; Fekete, S. Resolution of parentage in dogs by examination of microsatellites after death of putative sire: case report. Acta Vet. Hung., 2001, 49, 269273.

[20] Vila, C.; Walker, C.; Sundqvist, A.K.; Flagstad, O.; Andersone, Z.; Casulli, A.; Kojola, I.; Valdmann, H.; Halverson, J.; Ellegren, H. Combined use of maternal; paternal and bi-parental genetic markers for the identification of wolf-dog hybrids. Heredity, 2003, 90, 17-24.

[21] Eichmann, C.; Berger, B.; Reinhold, M.; Lutz, M.; Parson, W. Canine-specific STR typing of saliva traces on dog bite wounds. Int. J. Legal. Med., 2004, 118, 337-342.

[22] Halverson, J.L.; Basten, C. Forensic DNA identification of animalderived trace evidence: tools for linking victims and suspects Croat. Med. J., 2005, 46, 598-605.

[23] Holmes, N.G.; Dickens, H.F.; Parker, H.L.; Binns, M.M.; Mellersh, C.S.; Sampson, J. Eighteen canine microsatellites. Anim. Genet., 1995, 26, 132-133.

[24] Clark, L.A.; Famula, T.R.; Murphy, K.E. Evaluation of a rapid single multiplex microsatellite-based assay for use in forensic genetic investigations in dogs. Am. J. Vet. Res., 2004, 65, 1446-1450.

[25] DeNise, S.; Johnston, E.; Halverson, J; Marshall, K.; Rosenfeld, D.; McKenna, S.; Sharp, T.; Edwards, J. Power of exclusion for parentage verification and probability of match for identity in American kennel club breeds using 17 canine microsatellite markers. Anim. Genet., 2004, 35, 14-17.

[26] Eichmann, C.; Berger, B.; Parson, W. A proposed nomenclature for 15 canine-specific polymorphic STR loci for forensic purposes. Int. J. Legal Med., 2004, 118, 249-266.

[27] Halverson, J.L.; Basten, C. A PCR multiplex and database for forensic DNA identification of dogs. J. Forensic Sci., 2005, 50, 352-363.

[28] Hellmann, A.P.; Rohleder, U.; Eichmann, C.; Pfeiffer, I.; Parson, W.; Schleenbecker, U. A proposal for standardization in forensic canine DNA typing: allele nomenclature of six canine-specific STR loci. J. Forensic Sci., 2006, 51, 274-281.

[29] van Asch, B.; Alves, C.; Gusmão, L.; Pereira, V.; Pereira, F.; Amorim, A. A new autosomal STR nineplex for canine identification and parentage testing. Electrophoresis, 2009, 30, 417-423.

[30] Kanthaswamy, S.; Tom, B. K.; Mattila, A. M.; Johnston, E.; Dayton, M.; Kinaga, J.; Joy-Alise Erickson, B.; Halverson, J.; Fantin, D.; Denise, S.; Kou, A.; Malladi, V.; Satkoski, J.; Budowle, B.; Glenn Smith, D.; Koskinen, M.T. Canine Population Data Generated from a Multiplex STR Kit for Use in Forensic Casework. $J$. Forensic. Sci., 2009, May 26, [Epub ahead of print].

[31] Gill, P.; Brinkmann, B.; d'Aloja, E.; Andersen, J.; Bar, W.; Carracedo, A.; Dupuy, B.; Eriksen, B.; Jangblad, M.; Johnsson, V.; Kloosterman, A.D.; Lincoln, P.; Morling, N.; Rand, S.; Sabatier, M.; Scheithauer, R.; Schneider, P.; Vide, M.C. Considerations from the European DNA profiling group (EDNAP) concerning STR nomenclature. Forensic. Sci. Int., 1997, 87, 185-192.

[32] Edwards, A.H.; Hammond, A.; Jin, L.; Caskey, C.T.; Chakraborty, R. Genetic variation at five trimeric and tetrameric tandem repeat 
loci in four human population groups. Genomics, 1992, 12, 241253.

[33] Zhivotovsky, L.A.; Rosenbert, N.A.; Feldman, M.W. Features of evolution and expansion of modern humans; inferred from genomewide microsatellite markers. Am. J. Hum. Genet., 2003, 72, 1171-1186.

[34] Zhivotovsky, L.A.; Bennet, L.; Bowcock, A.M.; Feldman, M.W. Human population expansion and microsatellite variation. Mol. Biol. Evol., 2000, 17, 757-767.

[35] Mariat, D.; Kessler, J.L.; Vaiman, D.; Panthier, J.J. Polymorphism characterization of five canine microsatellites. Anim. Genet., 1996, $27,434-435$
[36] Mellersh, C.S.; Holmes, N.; Binns, M.; Sampson, J. Dinucleotide repeat polymorphisms at four canine loci (LEI 003; LEI 007; LEI 008 and LEI 015). Anim. Genet., 1994, 25, 125-126.

[37] Khan, S.; Shiyuba, H.; Nonneman, D.; Liu, P.C.; Huang, T. H-M.; Johnson, G.S. A polymorphic (TG)n microsatellite in an intron of the canine tyrosine transaminase gene. Anim. Genet., 1998, 29, 322-332.

[38] Parra, D.; Dolf, G.; Dunner, S. Contribution of a new set of canine microsatellites to the knowledge of the canine genetic map. Anim. Genet., 2003, 34, 69-70.

(C) Parra et al.; Licensee Bentham Open.

This is an open access article licensed under the terms of the Creative Commons Attribution Non-Commercial License (http://creativecommons.org/licenses/by-nc/3.0/) which permits unrestricted, non-commercial use, distribution and reproduction in any medium, provided the work is properly cited. 